\title{
THE QUESTION OF LEGITIMIZING LAW IN ADOLF REINACH'S PHENOMENOLOGY
}

\begin{abstract}
When speaking about legitimizing law we can mainly mean analysis which concerns metaphysical justification for what is called the phenomenon of law. From the metaphysical point of view, the justification of law means indicating the foundation of its existence. It is about seeking (indicating) an esse (essence) basis of law, in line with the task set by the metaphysical analysis, namely seeking an answer to the question: Why does object X exist? And in the answer, there will appear a formula indicating the final reasons for its existence (ratio essendi). The same ideas that we can find in Adolf Reinach's principal work, The Apriori Foundations of the Civil Law, provide a possibility of better understanding this important issue of legal philosophy, namely the question of legitimizing law (justifying law). The aim of this article is to present that argument.
\end{abstract}

Keywords: legal phenomenology, legitimizing law, positive law, speech acts theory, soziale Akte.

\section{INTRODUCTION}

The same ideas that we can find in Adolf Reinach's principal work, The Apriori Foundations of the Civil Law, provide a possibility of better understanding an important issue of legal philosophy, namely the question of legitimizing law (justifying law). If we enrich and complete these ideas with similar remarks from Roman Ingarden's ontology, we can, in my opinion, give quite a coherent and convincing argument on this issue.

In the introduction to his main work, Reinach stated "[...] we may hope that the apriori theory of right (die apriorische Rechtslehre) can here and there make a clarifying contribution even to the history of law. But it seems to us quite indispensable for the positive law as such. As long as one thinks that the positive law produces all concepts of right itself, one can only encounter a perplexity here. The structure of the positive law can only become intelligible through the structure of the non-positive sphere of law" (Reinach 1983, 7). ${ }^{1}$

*The University of Lodz, tomaszbekrycht@wpia.uni.lodz.pl

${ }^{1}$ In the original version: "So dürfen wir hoffen, daß die apriorische Rechtslehre auch der Rechtsgeschichte hier und da einen klärenden Beitrag zu liefern vermag. Ganz unentbehrlich aber scheint sie uns zu sein für das Verständnis des positiven Rechtes als solchen. Solange man daran glaubt, daß dieses alle rechtlichen Begriffe selbst erzeugt, muß man hier vor einem Rätsel stehen. 
We see that in spite of strictly separating these two spheres, i.e., positive law and non-positive normativity, as Reinach strongly outlined in many places of his book, he perversely noticed that we are able to understand the structure of positive law only through the structure of non-positive law. I think that this includes the question of its legitimation.

\section{TWO TRADITIONS OF LEGITIMIZING LAW}

When speaking about legitimizing law, I mainly mean analysis that concerns metaphysical justification for what is called the phenomenon of law. From the metaphysical point of view, the justification of law means indicating the foundation of its existence. It is about seeking (indicating) an esse (essence) basis of law, in line with the task set by the metaphysical analysis, namely seeking an answer to the question: Why does object X exist? And in the answer, there will appear a formula indicating the final reasons for its existence (ratio essendi). ${ }^{2}$

It could be said that legitimizing law, understood as justifying the existence of law, can be treated as a transcendental issue, because a question arises here about the conditions of the existence of law. This problem concerns both the structure of positive law and the structure of non-positive normativity.

The philosophical process of legitimizing law has two characteristic cores. Historically, the first of these is the legitimizing based on the concept of transcendence, and a transcendent being that is located spatially and temporally 'outside' the subject. In other words - metaphorically speaking - the law comes from the outside, meaning that in terms of the source of its existence (onto-genesis) it is based on some being that is, or has always been, beyond or above the subject in the sense of spatiotemporal or in the phenomenological sense as material apriori (opposed to formal apriori).

The scholarly literature of the subject (e.g. Welte, 1985; van der Leeuw 1970; Strauss 1999; Barbour 1976) reveals that two such transcendent sources were identified as externally legitimizing the law.

The first one was identified with God; the second with nature (conceived of in naturalism or non-naturalism terms). This can be expressed in the following way: the transcendental argument legitimizing the law is premised on transcendence in the form of God (religious tradition or philosophy of religion) or nature. ${ }^{3}$

Die Struktur des positiven Rechtes kann erst durch die Struktur der außerpositiv-rechtlichen Sphäre verständlich werden“" (Reinach 1989, 146-147).

${ }^{2}$ Whereas I do not mean legitimizing as explanations concerning motivation to observe the law (these can be diverse and are often determined by the content of law).

${ }^{3}$ Nota bene there is a rather complicated relationship between them, i.e. between the understanding of God and nature. Added to this is the issue of natural law (of course, usually 
The second core for legitimizing law is the subject itself (as law-giver), its immanence, i.e. consciousness, rationality, intelligence and reason as the source of law, which is external to and separate from law itself. Here, the ontological basis of law is human beings, understood as creatures endowed with rationality, not necessarily idealized - but in their rationality they are able to actively constitute principles and laws, as a transcendental I 'from the inside', as it were.

The issue here is an understanding of humanity which is completely antinaturalistic (even though rationality is an innate quality of the human being, the quintessence of their humanity). In other words, it is a desubstantialized (noumenal) self, having its centre and its ontic nature grounded in purely intelligible subjectivity, a pure self, which we can only posit and think of as a source of self-acting, unconditioned activity (agency), devoid of substance and elusive in experience. In this and exactly this sense, one can speak of the transcendental (and immanently human) justification for the existence of law. ${ }^{4}$

\section{LEGITIMIZING LAW AND POSITIVE LAW IN ADOLF REINACH'S THEORY OF SOCIAL ACTS}

Phenomenology, and particularly Adolf Reinach himself, has made significant contributions to the issue of legitimizing law, thus understood i.e., indication of its ontological grounds. The method of a phenomenological analysis, especially eidetic reduction, has allowed, firstly:

- precise separation from one another of such phenomena as the phenomenon of law as such, the phenomenon of positive law, the phenomenon of a legal norm, and the phenomenon of a moral norm; secondly:

- eidetic reduction does not allow for their (the phenomena) mutual reduction (i.e. for equivocation); thirdly:

- eidetic reduction should reveal to us the essence of an object, i.e. it should describe relations between 'ideal qualities' in the framework of a given ideal object. $^{5}$

In the third case, it should be observed that these relations are not, however, intellectually recognized in a straightforward manner, because they comprise areas of existence (more precisely, a mode of existence), of matter (more precisely, quality contents) and of form (more precisely, attributes of the entity).

understood in an anti-naturalism way), which is often derived from the concept of God, or a concept that 'absorbs' this concept.

${ }^{4}$ Comprehensive and detailed analysis of this problem can be found in my book (Bekrycht 2015).

${ }^{5}$ Details about this can be found in several works written by the philosophers of early phenomenology and in a lot of studies concerning these works (e.g. Husserl 1901; Reinach $1912-$ 1913; Lipps 1929; Conrad-Martius 1929). 
"Every object (any something whatsoever) - writes Roman Ingarden - can be regarded from three different points of view: first, with respect to its existence and mode of existence; second, with respect to its form; third, with respect to its material endowment" (Ingarden 2013, 87).

Thus, in the process of obtaining knowledge of the object, we have three types of ontological problems: 1) existential-ontological questions, 2) formal-ontological questions, and 3) material-ontological questions. The first requires us to answer the question about the proper mode of existence and the reason for existence, the second - which form the object takes, and the third - which variables and constants figure in the idea of the given subject, in other words the relations between the qualities in the content of the idea of this object.

Thus, the essence of the object is not a bundle of properties that appear with the greatest statistical frequency in the characteristics of a given object, but is rather part of a very complex picture that we often seek to reduce to a formula, by means of a (real) definition; yet this is simply impossible with many objects.

In his analyses, Reinach begins from an analysis of the phenomenon of law as law, and then moves on to the analysis of the phenomenon of positive law in the line with his assumption given in the introduction to The Apriori Foundations of the Civil Law, which is quoted above.

\subsection{Primal phenomenon of law}

According to the phenomenological analysis, we must reduce our knowledge to original phenomena and to the original moment at which we start perceiving law, ${ }^{6}$ for whose nature we intuitively search. And we can say that the relation with another entity (person, subject) is this primary moment. The concept of law, which constitutes a specific phenomenon of the relations between entities, we could say because of nature (apriori) itself, always assumes the existence of the second subject, but apart from this, something else, namely an empathetic attitude to it. It is the attitude of demanding something from the other entity or necessity of behaving in a certain way towards it. This is the original phenomenon which we call law. In jurisprudence, it assumes the form of a linguistic expression: 'a claim', 'an obligation' and 'a right'.

Of course, in jurisprudence, the expression 'a right' (Recht) is, however, understood and used in a broader sense than the concept of 'a claim' (Anspruch), as indicated by Reinach. In jurisprudence, we speak about the right to property and rights in rem or about the individual (legal) rights. However, each of these concepts is always secondary to the concept of a claim and is tied up with many assumptions, inter alia the assumption of the existence of positive law, the contents

${ }^{6}$ See also Lorenzo Passerini Glazel “Grasping an Ought. Adolf Reinach's Ontology and Epistemology of Legal and Moral Oughts", in this issue. 
of which, for example, grant a given subject the right to property, or is inextricable from the assumption of the existence of a metaphysical source from which the claim is derived, such as the right to life.

Reinach indicates these assumptions when he describes the two spheres (the concept of positive law and his apriori theory of right) and warns us not to mix these concepts.

A claim and obligation will, however, always remain an original phenomenon, i.e., the possibility of demanding something from someone, or the necessity of performing certain conduct towards someone. Such an original phenomenon of the intersubjective relation is characteristic of the areas which are generally determined as the social activity of a human being. However, there are numerous areas of mutual claims and obligations. These are traditionally called:

a) Morality,

b) Enacted law (positive law),

c) Customs.

The idea of law (as a connection and relation between a claim and an obligation) and thus described may now be subject to an ontological analysis in accordance with the areas distinguished above, namely of material and ontological, formal and ontological, existential and ontological research, according to Roman Ingarden's analysis $(2013,95-160){ }^{7}$

Reinach performs his analyses with respect to existential and ontological, material and ontological issues, while at the same time writing nothing about formal and ontological issues.

In a very general way, it could be said here that the idea of law assumes two inseparable moments, namely the claim and the obligation. For example, Ernst Tugendhat, like Reinach, accepts that speaking formally about rights (understood as claims) can be structured only by speaking about obligations (Tugendhat 1993, 336-363). These two moments constituting the original phenomenon are the starting point for the analysis of the qualitative contents of its idea. The claim and obligation require bearers (die Träger). It is a certain relationship of necessity, because the claim is always someone's claim towards someone else, and the obligation is the possibility of demanding satisfaction of the claim from its bearers.

Further on, a question arises about the form of law, i.e. the necessity of investigating the idea of law in the formal and ontological dimension. According to ontology, there is a close relationship between the form and material aspects of the entity, as pointed out by Roman Ingarden (1987, 291-314).

From the analysis of the qualitative contents of the idea of law, the stricte relative, correlative (comparative) nature of law as law is derived. The counterpart

7 "No one before Ingarden revealed and clarified such a wealth of existential moments and no one before him carried out such compelling analysis of modes of being" (Stróżewski 2005, 285-286). 
of a right (understood as a claim) is the obligation and necessity-based existence of bearers: 'A is obliged to B' and ' $\mathrm{B}$ has a claim against A'. This indicates that law assumes the form of a relationship and bearers as " $[\mathrm{t}] \mathrm{he}$ objects forming the elements of the relationship not only materially determine the «core» of the relationship but are also a purely ontological foundation of the existence of the relationship core and thereby also the relationship itself" (Ingarden 1987, 299). As Roman Ingarden indicates, the form of the relationship is characterised by the fact that at least two objects (subjects) occur in it, bearers of the relationship which, together with this special relation attributable to them, constitute one whole of a higher order.

Moving on, Reinach asks, firstly, what decides that someone (something) becomes an element of the relation? Then, secondly, when is it formed, so that law is in fact (I mean in reality) created (in other words what makes that law appears in reality)? Thereby, the question about the justification for law, apart from the strictly metaphysical issue, also comprises causal issues.

Thus, the first question, namely about the qualitative contents of the bearers of the law relationship is firstly an ontological (eidetic) question ${ }^{8}$ and then a metaphysical one. Thereby in the first and second case it has the task of indicating the source of law as its ontological foundation (firstly as an opportunity, and then factual). The second one is a causal question.

Answering the first question (that is, what decides that someone/something becomes an element of the relation), we can say that the necessary condition for the existence of the law relations is the situation where a communicative relation appears, which indicates that the bearers of the law relations can only be such entities which can communicate with one another, i.e. can understand the meaning of stated words or, speaking more generally, they must possess and use the same meanings irrespective of who (or what) are the bearers of a relationship.

Reinach determined the necessary condition as the need to be heard (die Vernehmungsbedürftigkeit) which means a requirement to acknowledge the contents of the statement (Reinach 1983, 19; Reinach 1989, 159-160). In other words, the bearer of the law relation can be any type of essence as long as it meets this requirement. Thereby, from the point of view of ontology we can speak about two sources i.e. the ontological bases of the existence of law. The first source is the occurrence of a communicative situation, the other source is that there is an entity, and more precisely entities, that can take part in the communication. What is important here is the fact that in the ontological analyses we have reached the possibility of setting conditions for the existence of law.

8 "Ontological deliberation consists in the apriori analysis of the contents of ideas. It has its ultimate foundation in the pure apprehension of the most primitive ideal qualities (of 'pure Wesenheiten') and of the necessary interconnections binding them (Ingarden 2013, 61-62). This needs eidetic reduction. 
Summing up, we can say that its ontological condition is the existence of at least two entities/subjects i.e. bearers and the communicative situation, which from the formal and ontological points of view gives us the relation as a form of law.

The second question, the most important for us here, is the question of what the source of law creation (understood as relation between a claim and an obligation) is, i.e. how it happens that the communicative situation creates law, i.e. a claim-obligation relation.

It is, however, a question not only about the source of law creation but mainly about the possibility of the communicative situation occurring. In these terms, it is a transcendental question about the conditions of communicative opportunities.

Reinach's answer to this question is the concept of social acts (soziale Akte). ${ }^{9}$ The introduction of this concept and its analysis have considerable significance for the process of legitimizing law because it indicates the existence of the communicative Apriori, which, it can be said, constitutes the final reason in the metaphysical justification for law, as it is the final i.e. transcendental element of the process.

Reinach emphasizes the primordiality of some social acts, especially the act of a promise (das Versprechen) and stresses the impossibility of their cognitive reduction to more elementary elements, thereby accepting their transcendental character. Only a few social acts may have an apriori structure, inter alia: promises, statements (assertions), questioning, commanding, requesting (Reinach 1983, 18-49; Reinach 1989, 158-189).

Summing up the past research results, we may accept that eidetic analyses of the phenomenon of law as indicating that the law as law is a relation with two fundamental constants as ideal qualities i.e. a claim (right) and an obligation, and their bearers. This relation is created apriori, as the result of communicative action by the fulfilment of a promise as a social act.

\subsection{Positive law}

And now the question of positive law and its legitimizing arises.

The above conclusions apply to positive law, with some modifications, in accordance with the quotation from the introduction to The Apriori Foundations

\footnotetext{
${ }^{9}$ In Anglo-Saxon philosophy (analytical philosophy and analytical jurisprudence) attribute the theory of speech acts to John Langshaw Austin (and then John Rogers Searle). Historically, the relationship between these two concepts raises a paradox, because as the creator of the theory is normally be considered to be Austin, not Reinach. But Austin created it in the 1950s (Austin 1962), decades after the publication Reinach's work Die apriorischen Grundlagen des bürgerlichen Rechtes (Reinach 1913). Unfortunately, for a number of historical reasons the theory of social acts was forgotten - Reinach's premature death, Husserl's deviating from ideas of early phenomenology, the political situation after 1933, problems with understanding the method of phenomenological (eidetic) reduction, or phenomenological analysis in general. For these reasons, it is likely that Austin did not know about this theory.
} 
of the Civil Law (the structure of positive law can only become intelligible through the structure of the non-positive sphere of law). The distinction between law as law and positive law, in terms of the problem of legitimizing, lies not in other ontological grounds - these are the same: the bearers of relationship and apriori in the sphere of social acts. The difference is founded on other kinds of social acts.

Reinach points out that to legitimize positive law we can find other acts that create its structure. A promise is not enough to create positive law, because we would only have a claim on the side of the law-maker and an obligation on the side of the addressee.

The structure of positive law cannot be built on the grounds of a promise, i.e., on a claim and an obligation, since it is too weak. We must find something stronger. Why? Because a phenomenon of positive law should contain a potential element of coercion to enforce its norm and not a claim in the content of which there is such enforcement. It is not an act of promise that built the structure of positive law.

Reinach indicates that it is the act of enacting (Bestimmungsakt) ${ }^{10}$ that creates normativity as positive law (Reinach 1983, 106; Reinach 1989, 243). However, in my view the act of enacting (Bestimmungsakt) must be completed by another act which is accomplishment by the addressee. However, Reinach did not write about this. It is my contention that if the normativity given by the law-maker is to have a result in sphere of the addressee, they have to grant that capability.

This act can be called the act of granting the general legislation provision or the act of granting validity-specifying provisions (Geltungsanordnungen - following Karl Larenz and his paper Rechtssatz als Bestimmungssatz), (1969, 154). That act is addressed to the law-maker and, in view of causal arguments justifying positive law, legitimizes its existence (the existence of the relationship between addressee/subjects of positive law and the law-maker).

This leads us to the analysis of three important concepts in the question of the legitimacy of positive law, i.e. the notions of the lawmaker, the sovereign and power. These concepts can be reconstructed with the help of Reinach's theory.

The sovereign is a subject (in the broadest sense of this word) who has power (P1), but in the sense of the ability to be empowered, so as to define itself, on the one hand, as a unified political entity, and, on the other hand, as the entity that decides on the form and type of given political existence in which the legislator is designated (legitimized). The sovereign can only be a subject who is an addressee of the law - the addressee of acts of enactment (Bestimmungsakte), because it is the sovereign who constitutes itself as a political unity, i.e. agrees to be the addressee of norms and constitutes an internal - as Herbert Hart said - attitude of acceptance of the law and the reason for its observance $(1961,86-88)$. Regardless of how we

${ }^{10}$ Stanley L. Paulson translates the term Bestimmungsakt as 'the act of issuance' and the term Bestimmung as 'the legally issued norm' (Paulson 1987, 149-152). 
refer to this subject - whether as a nation, a community, a community, a people, or a state - it is this subject (as sovereign) that determines the effectiveness of enacting (as the addressee of the law). If there is no such acceptance (inner attitude), the only remaining recourse is force.

However, analysis at the conceptual level - in accordance with the assumptions of the method of phenomenological analysis - must also take into account the actual idea of sovereignty. Unfortunately, at the level of factuality we are not able to empirically pinpoint this subject or its normative actions. Habermas, one of the leading contemporary social philosophers, stresses that "popular sovereignty is no longer embodied in a visibly identifiable gathering of autonomous citizens. It pulls back into the, as it were, 'subjectless' forms of communication circulating through forums and legislative bodies" (Habermas 1996a, 135-136). Sovereignty is thus the highest institutional abstraction, belonging to one of the notions of the symbolic universe, which justifies (legitimizing) positive law. Therefore, in order for the sovereign to make normative decisions and to actually shape the content of social relations, an organizational principle must appear which is founded on an act of granting validity-specifying provisions, which determine the institution of power, but not understood as 'possibility' ('power), but as 'submission' to the will of the legislator and its vision of social relations, and in particular its requirements with regard to conduct. This principle is the idea of positive law - the rule of law (P2). "Political power - writes Habermas - is not externally juxtaposed to law but rather presupposed by law and itself established in the form of law" (Habermas 1996a, 134). The fact that we usually wrest the notion of positive law away from the notions of power and the State is an error that has its foundation in empiricism (Loidolt 2009, 21-22). Habermas points out that law is perceived and often functions as an instrument of power, but at the same time stresses that this is a distortion resulting from the fact that in such cases we are actually dealing with the phenomenon of illegitimate power. Power and law mutually constitute each other, hence the notion of power at issue here can be termed 'legitimate power'. However, the contemporary complexity of social relations has overshadowed the phenomenon of positive law, which - according to Habermas - can be correctly reconstructed using examples of abstractly conceived primitive communities, in which one can see the phenomenon of the transformation of power as authority into power as a legitimized institution. According to Habermas, there are two processes that occur simultaneously, uno acto, i.e. power is authorized by an essential value, usually sacred law, and at the same time law is sanctioned by this power. Therefore, we must therefore distinguish, as Habermas stresses, the functions that power and law perform for each other, from the functions of law and power in their own right (Habermas 1996a, 137-144). In other words, if power is legitimized, then we are dealing with a proper relationship of law (legitimate power).

Habermas argues that positive law is a remedy for the complexity of social relationships in increasingly diverse and complex communities, where 
the processes of reaching agreement are very likely to end in divergence and disagreement. Positive law - according to Habermas - derives its justification from the "alliance" of two elements, i.e. the normative decision of the legislator and the expectations of the sovereign, meaning the addressee of this normativity. Hence "[t]his ideal tension reappears in the law. Specifically, it appears in the relation between the coercive force of law, which secures average rule acceptance, and the idea of self-legislation (or the supposition of the political autonomy of the united citizens), which first vindicates the legitimacy claim of the rules themselves, that is, makes this claim rationally acceptable" (Habermas 1996a, 39).

He reconstructs the whole idea as follows: the construction of positive law begins with the principle of discourse, which gives this principle a legal form, in order to ensure, on the one hand, freedom of action and, on the other, the discursive realization of political autonomy. Thus, a given community of law is defined legally, both as a political unity and an axiological unity. And, in this sense, we give law (rights) unto ourselves, that is, we 'keep power alive', as a tool for realizing this idea. Thus, the content of the law "[...] does not exist in transcendental purity" (Habermas 1996a, 129). ${ }^{11}$

Thus, we can say that the theory of social acts is the foundation for justifying law beyond concepts referring to transcendent entities and the philosophical-legal concepts based on them, such as theological concepts or natural law concepts.

\section{CONCLUSION}

The analysis of the problem of legitimizing positive law from the perspective of Adolf Reinach's transcendental theory of social acts demonstrates the necessity of the joint existence (fulfilment) of two such acts - the act of granting validityspecifying provisions and act of enactment. This led us to the analysis of three important concepts in the question of the legitimacy of positive law, i.e. the notions of the law-maker, the sovereign and power. These concepts I synthetically tried to reconstruct with the help of Reinach's theory.

\section{BIBLIOGRAPHY}

Austin, John L. 1962. How to do Things with Words. The William James Lectures delivered at Harvard University in 1955. Oxford: Oxford University Press.

Barbour, Ian G. 1976. Myths, Models and Paradigm. A comparative Study in Science and Religion. New York: Harper and Row Publisher.

Bekrycht, Tomasz. 2015. Transcendentalna filozofia prawa. O zewnętrznym obowiąywaniu i uzasadnieniu istnienia prawa. Łódź: Wydawnictwo Uniwersytetu Łódzkiego.

${ }^{11}$ Habermas sees the legitimization of contemporary legal systems as residing in the idea of the self-determination of the legal community, which reaches this agreement in discourse. 
Conrad-Martius, Hedwig. 1929. "Farben. Ein Kapitel aus der Realontologie”. Jahrbuch für Philosophie und phänomenologische Forschung. Edmund Husserl zum 70. Geburtstag gewidmet 10: 339-370.

Habermas, Jürgen. 1996a. Between Facts and Norms. Contributions to a Discourse Theory of Law and Democracy. Translated by William Rehg. Massachusetts: The MIT Press.

Hart, Herbert L.A. 1961. The Concept of Law. Oxford: Oxford University Press.

Husserl, Edmund. 1901. Logische Untersuchungen. Zweiter Teil. Untersuchungen zur Phänomenologie und Theorie der Erkenntnis. Halle: Max Niemeyer.

Ingarden, Roman. 1987. Spór o istnienie świata. Tom II. Ontologia formalna. Część 1. Forma $i$ istota. Warszawa: PWN.

Ingarden, Roman. 2013. Controversy over the Existence of the World. Volume I. Translated by Arthur Szylewicz. Frankfurt am Main: Peter Lang.

Larenz, Karl. 1969. "Der Rechtssatz als Bestimmungssatz". In Festschrift für Karl Engisch zum 70. Geburstag. 150-160. Edited by Paul Bockelmann, Arthur Kaufmann, Ulrich Klug. Frankfurt am Main: Vittorio Klostermann.

Lipps, Hans. 1929. "Das Urteil". Jahrbuch für Philosophie und phänomenologische Forschung. Edmund Husserl zum 70. Geburtstag gewidmet 10: 282-296.

Loidolt, Sophie. 2009. Anspruch und Rechtfertigung. Eine Theorie des rechtlichen Denkens im Anschluss an die Phänomenologie Edmund Husserls. Dordrecht: Springer.

Paulson, Stanley L. 1987. "Demystifying Reinach's Legal Theory". In Speech Act and Sachverhalt. Reinach and the Foundations of Realist Phenomenology. 133-154. Edited by Kevin Mulligan. Dordrecht: Matinus Nijhoff.

Reinach, Adolf. 1983. "The Apriori Foundations of the Civil Law". Aletheia 3: 1-142.

Reinach, Adolf. 1989. "Die apriorischen Grundlagen des bürgerlichen Rechtes". In Sämtliche Werke. Textkritische Ausgabe 1. Werke. 141-278. Edited by Karl Schumann, Barry Smith. München: Philosophia Verlag.

Strauss, Leo. 1999. Natural Right and History. Chicago-London: The University of Chicago Press. Stróżewski, Władysław. 2005. Istnienie i sens. Kraków: Znak.

Tugendhat, Ernst. 1993. Vorlesungen über Ethik. Berlin: Suhrkamp.

van der Leeuw, Gerardus. 1970. Phänomenologie der Religion. Tübingen: J.C.B. Mohr (Paul Siebeck).

Welte, Bernhard. 1985. Religionsphilosophie. Freiburg i. Br.-Basel-Wien: Herder. 